\title{
Avaliação de Doenças Foliares nos Ensaios Estadual e Regional de Trigo no Rio Grande do Sul
}

\author{
Rafael M. Soares ${ }^{1} \&$ Ricardo L. Castro ${ }^{2}$ \\ 'FEPAGRO Sementes, CEP 98130-000, Júlio de Castilhos, RS, fone/fax: (55) 271-1504, e-mail: rafael-soares@ @epagro.rs.gov.br; \\ ${ }^{2}$ FEPAGRO Cereais, CEP 97670-000, São Borja, RS, fone/fax: (55) 431-2666, e-mail: ricardo-castro@ fepagro.rs.gov.br
}

(Aceito para publicação em 02/09/2003)

Autor para correspondência: Rafael M. Soares

\begin{abstract}
Evaluation of leaf diseases in the state and regional wheat assays of Rio Grande do Sul

The objective of this work was to evaluate the incidence and severity of the main wheat (Triticum aestivum) leaf diseases (leaf spots,

powdery mildew and leaf rust) on genotypes of wheat in the Regional Assay, and cultivars in the State Assay, accomplished at FEPAGRO Sementes, in Júlio de Castilhos, RS. The results compared the reaction of genotypes to each separate disease.
\end{abstract}

A cultura do trigo (Triticum aestivum L.) está sujeita ao ataque de diversas doenças. O uso de cultivares resistentes é a medida de controle preferencial. A quebra da resistência torna constante a produção de novas cultivares.

As cultivares recomendadas para cultivo nos estados do Rio Grande do Sul e Santa Catarina são aprovadas pela Comissão Sul-Brasileira de Pesquisa de Trigo (CSBPT), baseadas nos resultados dos ensaios Estaduais e Regionais.

Este trabalho objetivou avaliar a incidência (I) e severidade $(\mathrm{S})$ das principais doenças foliares da cultura do trigo nos ensaios Regional e Estadual, realizados na FEPAGRO Sementes, em Júlio de Castilhos, RS, no ano de 2002.

As avaliações de doenças foram realizadas em parcelas únicas, coletando-se dez folhas por parcela. Para avaliação de $\mathrm{S}$ da ferrugem da folha, usou-se a escala diagramática de Peterson et al. (Stubbs et al., Manual de metodologia sobre enfermedades de los cereales, CIMMYT, 1986). Para as manchas, foliares usaram-se as escalas de James (James, Canadian Plant Disease Survey 51:30. 1971) e de Eyal et al. (Eyal et al., Septoriosis de la gluma..., CIMMYT, 1983). Para a avaliação da $\mathrm{S}$ do oídio não foi utilizada nenhuma escala. As avaliações foram realizadas na floração plena do trigo.

Os resultados (Tabela 1) indicaram que tanto as cultivares como as linhagens mostraram-se mais suscetíveis às manchas foliares do que ao oídio e à ferrugem da folha, mostrando que as cultivares, até hoje desenvolvidas, não têm apresentado uma resistência completa às manchas (poligênicas). Por outro lado, tem-se obtido genótipos resistentes ao oídio e à ferrugem (governadas por poucos genes), mas essa resistência é ciclicamente quebrada devido às características de mutabilidade dos patógenos. Isso também explica a menor $\mathrm{S}$ e I nas linhagens em relação às cultivares, pois as primeiras ainda não sofreram a pressão de seleção de sucessivos cultivos.
TABELA 1 - Percentual de severidade (S) e incidência (I) de doenças foliares do trigo (Triticum aestivum) nas cultivares do Ensaio Estadual, e linhagens do Ensaio Regional no ano de 2002

\begin{tabular}{|c|c|c|c|c|c|c|}
\hline \multirow[t]{2}{*}{ Cultivar } & \multicolumn{2}{|c|}{$\begin{array}{l}\text { Manchas } \\
\text { foliares }\end{array}$} & \multicolumn{2}{|c|}{ Oídio } & \multicolumn{2}{|c|}{ Ferrugem } \\
\hline & $\mathbf{S}$ & I & $\mathbf{S}$ & I & $\mathbf{S}$ & I \\
\hline Alcover & 3,4 & 100 & 0,3 & 30 & 2,3 & 60 \\
\hline BR 15 & 5,4 & 100 & 0,7 & 30 & 2,1 & 90 \\
\hline BR 18 Terena & 8,1 & 100 & 2,2 & 50 & 1,4 & 60 \\
\hline BR 23 & 5,5 & 100 & 0,2 & 20 & 2,5 & 40 \\
\hline BR 35 & 4,6 & 88 & 0,1 & 13 & 16,3 & 100 \\
\hline BRS 119 & 6,9 & 100 & 0,7 & 30 & 10,1 & 100 \\
\hline BRS 120 & 10,2 & 100 & 0 & 0 & 0,1 & 10 \\
\hline BRS 177 & 3,0 & 100 & o & o & 0,0 & 0 \\
\hline BRS 179 & 3,6 & 90 & 0,7 & 30 & 0,3 & 30 \\
\hline BRS 194 & 1,8 & 100 & 0 & o & 0,0 & 0 \\
\hline BRS 221 & 3,5 & 100 & 0 & 0 & 0,1 & 10 \\
\hline BRS 222 & 1,9 & 100 & o & o & 0,0 & 0 \\
\hline BRS 223 & 5,4 & 90 & 0,9 & 50 & 0,2 & 20 \\
\hline BRS 49 & 7,1 & 100 & 0 & o & 16,1 & 100 \\
\hline CEP 24-Ind. & 3,8 & 70 & 0,2 & 20 & 1,7 & 90 \\
\hline CEP 27-Mis. & 8,2 & 100 & 0 & 0 & 1,9 & 70 \\
\hline Embrapa 16 & 10,7 & 100 & 0 & o & 13,5 & 100 \\
\hline Embrapa 40 & 11,7 & 100 & 0,1 & 10 & 0,6 & 10 \\
\hline Embrapa 52 & 9,5 & 100 & 0 & o & 15,5 & 100 \\
\hline Fepagro 15 & 7,8 & 100 & 0,3 & 25 & 28,8 & 100 \\
\hline Fundacep 29 & 12,2 & 100 & 0 & 0 & 7,9 & 100 \\
\hline Fundacep 30 & 5,8 & 100 & o & o & 0,0 & 0 \\
\hline Fundacep 31 & 4,5 & 100 & 0,6 & 20 & 0,0 & o \\
\hline Fundacep 32 & 8,1 & 100 & 0,2 & 20 & 0,0 & o \\
\hline Fundacep 36 & 8,3 & 100 & 0,7 & 67 & 0,0 & o \\
\hline Fundacep 37 & 16,1 & 100 & 0 & 0 & 0,0 & o \\
\hline Fundacep 40 & 9,7 & 100 & o & o & 1,6 & 20 \\
\hline Granito & 8,7 & 100 & 0,2 & 20 & 0,1 & 10 \\
\hline Jaspe & 6,1 & 100 & 0,1 & 10 & 0,1 & 10 \\
\hline Ônix & 12,6 & 100 & o & 0 & 0,5 & 10 \\
\hline OR 1 & 1,3 & 67 & 18,3 & 83 & 35,8 & 100 \\
\hline RS 1 -Fênix & 7,8 & 100 & 1,1 & 63 & 5,0 & 100 \\
\hline Rubi & 8,2 & 100 & 11,2 & 90 & 0,0 & o \\
\hline CEP 0010 & 2,1 & 80 & 0 & 0 & 0 & o \\
\hline CEP 00105 & 8,5 & 100 & 0,3 & 30 & o & 0 \\
\hline CEP 0013 & 3,8 & 80 & 0,1 & 10 & o & o \\
\hline CEP 98104 & 2,2 & 90 & 0 & 0 & 0,2 & 20 \\
\hline CEP 99121 & 5,5 & 100 & o & o & 0 & 0 \\
\hline CEP 99131 & 7,7 & 100 & o & o & o & 0 \\
\hline CEP 9914 & 7,9 & 100 & 0 & o & o & o \\
\hline CEP 99171 & 8,6 & 100 & 0 & 0 & o & o \\
\hline CEP 99205 & 10,4 & 100 & o & 0 & o & o \\
\hline CEP 994 & 5,9 & 90 & o & o & 0,4 & 40 \\
\hline CEP 9967 & 3,9 & 100 & o & o & 0,1 & 10 \\
\hline CEP 9982 & 1,6 & 80 & o & 0 & o & 0 \\
\hline ORL 00408 & 1,3 & 90 & 0,1 & 10 & 0 & 0 \\
\hline ORL 99052 & 3,9 & 100 & 0 & o & o & o \\
\hline ORL 99074 & 4,4 & 90 & o & o & o & o \\
\hline ORL 99100 & 2,2 & 100 & 0 & 0 & 0 & o \\
\hline ORL 99124 & 3 & 100 & o & 0 & 1,9 & 70 \\
\hline ORL 99143 & 2,6 & 90 & 0,7 & 30 & 0,2 & 20 \\
\hline ORL 99192 & 2,3 & 90 & 0,2 & 20 & 0 & o \\
\hline ORL 99220 & 1 & 100 & 0 & 0 & o & 0 \\
\hline ORL 99382 & 2,6 & 100 & o & o & o & o \\
\hline ORL 99393 & 1,2 & 80 & o & o & 0,2 & 20 \\
\hline ORL 99396 & 5,5 & 100 & o & o & 0 & 0 \\
\hline SB 2076 & 9,3 & 100 & o & 0 & 0,9 & 50 \\
\hline SB 2031 & 4,1 & 100 & 1,6 & 40 & 2,8 & 70 \\
\hline SB 2051 & 3,5 & 100 & 0,1 & 10 & 1,7 & 90 \\
\hline
\end{tabular}

